\title{
Reflexión sobre la consideración del patrimonio paleontológico
}

Juan Carlos García Pimienta | facultativo superior en patrimonio cultural-paleontología (Dirección General de Cultura y Patrimonio, Diputación General de Aragón)

URL de la contribución <www.iaph.es/revistaph/index.php/revistaph/article/view/4159>

Resulta preocupante el dispar tratamiento y consideración que existe respecto al patrimonio paleontológico en el territorio español, lo que genera una gran confusión tanto al ciudadano como a los profesionales. Por un lado, hay una corriente, más filosófica que otra cosa, sobre si debe ser tratado por las leyes sobre patrimonio histórico o por las de medio natural como parte del patrimonio geológico. Aún más preocupante es, casi 40 años después de la promulgación de la Ley 16/1985 de Patrimonio Histórico Español, tener que retrotraernos a una cuestión fundamental previa a cualquier planteamiento futuro al respecto de la gestión de la paleontología y que parecía ya superada: ¿los fósiles han de ser protegidos? El régimen de protección y la regulación posterior ha de ser acorde a la consideración o valor que la sociedad dé a los fósiles.

Una regulación eficaz del patrimonio paleontológico pasa porque los entes implicados (científicos, políticos, sociedad) entendamos que se trata precisamente de eso, de un "patrimonio", cuya acepción derivada del derecho romano consiste en "el Conjunto de bienes heredados de los padres, en sentido amplio y que debe ser preservado para otras personas presentes y futuras, lo que necesariamente impone cargas y deberes y restringe su disponibilidad". Una vez considerado que nos encontramos ante un patrimonio, algo a conservar y proteger, hay que arbitrar todas las medidas normativas y administrativas necesarias para la consecución de ese fin.

La Ley 16/1985 de Patrimonio Histórico Español supuso un antes y un después para los convencidos de que los fósiles eran un patrimonio y por tanto debían de contar con un régimen de protección. Vieron en esta norma la fórmula para incluir los restos paleontológicos junto (aunque más bien subordinados) a los arqueológicos y asegurar así su reconocimiento. No obstante, la lectura permitía una doble interpretación del Art. 40.1 de la LPHE: "Forman parte, asimismo, de este patrimonio (arqueológico) los elementos geológicos y paleontológicos relacionados con la historia del hombre y sus orígenes y antecedentes":

A) Interpretar orígenes y antecedentes del hombre como el origen de la vida en la Tierra y por tanto tendrían cabida todos los restos paleontológicos.

B) Interpretar orígenes y antecedentes del hombre como restringido a los homínidos y por tanto tendrían cabida únicamente los restos paleontológicos asociados a contextos arqueológicos.

Aún haciendo una interpretación "generosa" desde el punto de vista paleontológico de la Ley 16/1985 (opción A), está claro que su articulado dejaría mucho que desear para una adecuada gestión del patrimonio paleontológico.

Una vez convencidos de la idea de que los fósiles son algo a conservar (un patrimonio) y viendo las carencias existentes en la LPHE, lo adecuado sería el desarrollo normativo (autonómico por la asunción de competencias por las CC. AA.) que significara: la definición del patrimonio paleontológico y de las cuestiones básicas: órgano competente responsable, condiciones de intervención, régimen de protección, figuras de protección, cuál debe ser su uso y destino, etc.

Aragón, por ejemplo, hizo un desarrollo inicialmente de la ley estatal y posteriormente se decantó por hacer una Ley propia (Ley 3/1999 de Patrimonio Cultural Aragonés) en la que: se separó el patrimonio arqueológico del pale- 
a debate El marco legal para la protección del patrimonio paleontológico. ¿Qué pasa en tu comunidad?

ontológico y, para ello, se definió qué es el patrimonio paleontológico (independiente del arqueológico) y se le otorgó la consideración de bienes de dominio público. Todo ello trajo consigo la creación de una infraestructura administrativa (entre ellas, la presencia en plantilla de dos plazas de funcionarios como Técnicos Facultativos en Patrimonio Cultural-Paleontología) o la inclusión de la existencia de este patrimonio paleontológico en otras normativas sectoriales (urbanística, ambiental, ordenación del territorio), etc.

Es preocupante que existan a día de hoy territorios que no reconozcan siquiera los fósiles como patrimonio (se suma una interpretación laxa de la Ley estatal y una nula voluntad autonómica de desarrollo propio). Pero es igual de preocupante que el patrimonio paleontológico siga estando subordinado al arqueológico en otros casos o que se tenga una regulación normativa pero luego no se den los pasos siguientes de creación de una mínima infraestructura administrativa que impulse y desempeñe las funciones de gestión que le compete (gestión de autorizaciones, informes sectoriales, control de expedientes, cumplimentación de bases de datos de yacimientos, etc.).

No hay ninguna duda de que los fósiles son bienes naturales que forman parte del patrimonio geológico y nada tienen que ver con el patrimonio histórico. Pero no hay que olvidar que estas normativas históricas o culturales son las que dieron pie indirectamente a la protección del patrimonio paleontológico y es únicamente por ello por lo que han seguido ligadas a los departamentos responsables del patrimonio histórico. Hay que tener en cuenta que el patrimonio geológico no se reconoce como tal en España hasta el año 2007 (Ley 42/2007, de 13 de diciembre, del Patrimonio Natural y de la Biodiversidad) y que el patrimonio paleontológico tiene unas connotaciones muy diferentes respecto a los bienes arqueológicos 0 históricos que dificulta su gestión común, pero éstas son tanto o más respecto a otros elementos naturales como son los glaciares, los pliegues, dolinas o las fallas. En Aragón, los fósiles son bienes de dominio público por sí mismos por la ley $3 / 1999$, algo que no lo son ninguno del resto de elementos geológicos.
Como funcionario, creo irrelevante que mi sitio se encuentre en una u otra planta de la misma administración si hay que llevar a cabo las mismas funciones y lo único que va a cambiar es qué cargo va a tener competencia en la firma en lo relativo al patrimonio paleontológico (el Director General de Cultura y Patrimonio o el de Medio Natural). Lo importante es que el patrimonio paleontológico tenga su reconocimiento como un "patrimonio", se lleve a cabo su gestión administrativa (supervisión de obras y actuaciones, protección, inventarios, se fomente su estudio, difusión, investigación, etc.), que los fósiles que se estudien vayan a un museo, y que las secciones, así como yacimientos sean conservados o se documenten antes de que desaparezcan.

El patrimonio paleontológico es un legado a proteger y el debate debe ir encaminado a establecer un diagnóstico del estado actual en cada territorio y las necesidades y mecanismos precisos para abordar su gestión. 